\title{
Impact of Compost Tea Types Application on Germination, Nodulation, Morphological Characters and Yield of Two Lentil Cultivars
}

\author{
Osama A.M. Ali ${ }^{(1) \#}$, Yasser A. El-Tahlawy ${ }^{(2)}$ and Shebl A. Abdel-Gwad ${ }^{(2)}$ \\ ${ }^{(1)}$ Crop Science Department, Faculty of Agriculture, Menoufia University, Menoufia, \\ Egypt; (2)Agricultural Microbiology Department, Soils, Water and Environment \\ Research Institute, Agricultural Research Center (ARC), Giza, Cairo, Egypt.
}

\begin{abstract}
T ABORATORY and field experiments were performed at Crop Science Laboratory and the Experimental Farm, respectively, Faculty of Agriculture, Menoufia University, Shebin El-Kom, Egypt, in order to evaluate the response of germination and seedling characters, nodulation, growth, nutrients uptake and yield of two lentil cultivars (Giza 4 and Family 29) to application of various compost tea types prepared from different agricultural residues (sugarcane bagasse, cotton stalk and rice straw) and their grades based on particles size (unfractionated, relatively coarse and fine). Application of compost tea includes twice ways applied together, i.e. seed priming before sowing and foliar application during growth periods ( 25 and 55 days after sowing). Results showed that Giza 4 significantly surpassed Family 29 for all parameters except germination \%. Giza 4 outweighed Family 29 by 19.36 and $11.30 \%$ for seed yield/fad in first and second seasons, respectively. The compost tea types produced from the finest particles size $(0.6-1 \mathrm{~mm})$ of the cotton stalk or rice straw compost revealed maximum values of germination and seedling characters, nodulation, growth, chlorophyll, NPK contents, yield and protein $\%$. The interactions between lentil cultivars and compost tea were found to be significant for studied characters. It could be concluded that treated Giza 4 with compost tea produced from finest particles size $(0.6-1 \mathrm{~mm})$ of cotton stalk or rice straw compost was found to be the best combination treatment for enhancing germination, nodulation, growth and productivity of lentil, indicating the importance of compost tea application to maximize lentil productivity.
\end{abstract}

Keywords: Agricultural residues, Particles size grades, Compost tea types, Yield, Lentil.

\section{Introduction}

Lentil (Lens culinaris Medik.) is a beneficial winter legume crop that has been globally cultivated as an important food source for over 8,000 years (Cokkizgin \& Shtaya, 2013 and Mitiku, 2016). Lentil provide a considerable portion of the nutrition of the people in the African countries. From the nutritional view, lentil seeds contains about $22-31 \%$ protein, $60-65 \%$ total carbohydrate, $0.6 \%$ fat, $4 \%$ fiber and $2.1 \%$ ash. Moreover, because the symbiotic nitrogen fixation attribute, lentil plants can be grown in rotation with cereal crops in order to reduce demand for nitrogenous fertilizers. On the other hand, lentil straw contains about 10.2, 4.4, 50, 1.8, 12.2 and $21.4 \%$ moisture, protein, carbohydrate, fat, ash and fiber, respectively, which increase interest for potential using it as forage for animal feeding (Roy et al., 2010 and Abbeddou et al., 2011), biomass energy crop and other industrial non-food uses (Yadav et al., 2007). However, the cultivated area estimated in Egypt has gradually decreased from 26,636ha $(\approx 63,393 \mathrm{fad})$ in 1961 and reached only about 611 ha $(\approx 1,454 \mathrm{fad})$ in 2016 with the productivity of 34,434 to 892 ton/ year, respectively (FAOSTAT, 2017).

In Egypt, the total amount of crop residues produced annually is about 38.7 million tons per year out coming from the cultivated area, which is about 3.7 million hectares ( 8.8 million fad) with a cropping area of about 6.2 million hectares (about 14.7 million fad) during years 20092013. Only about 7 million tons are being utilize as animal feed and about 4 million as organic manure (Hussein \& Sawan, 2010). The estimated amount of rice straw, cotton stalk and sugarcane

\#Corresponding author email: os ali2000@yahoo.com DOI: 10.21608 /agro.2018.5678. 1126

C2018 National Information and Documentation Center (NIDOC) 
bagasse are 3.6, 1.6 and 6.8 million ton per year, respectively, which represent about 9.5, 4.2 and $19.4 \%$ of total crop residues, respectively. The crop residues result after harvesting in the form of leaves and stem, which are characterized as coarse plant products and big size, chemically low in protein and fat contents, and high in lignin and cellulous contents (El-Shimi, 2016 and Elfeki et al., 2017).

The conventional farming has faced many criticisms because it greatly relies on many external inputs with a significant amount of synthetic agrochemicals like synthetic fertilizers, pesticides or growth regulators to produce the highest possible yield of crops (Lairon, 2010). On the other hand, sustainable or organic farming is an eco-friendly alternative option to conventional farming for stable yield and quality as well as greater spatial stability of soil biotic and abiotic properties (Suja et al., 2017 and Schrama et al., 2018). Under a sustainable farming, attempts are going to employ bioorganic compounds, including compost or its liquid phase (compost tea), for establish successful beneficial biological interactions, maximize reuse and preserve agro-ecosystem quality (Casado \& González de Molina, 2009 and Kapoor et al., 2015). In such context, Badawi et al. (2014) documented that the foliar application of bioenriched compost tea $(200 \mathrm{~L} / \mathrm{fad})$ acts as a good practice for improving the most growth and yield characters of lentil varieties (Sinaa 1 and Giza 9) and leading to healthier food, particularly under sustainable agricultural systems. Seed priming is a pre-sowing procedure impacting seedling development by stimulates pre-germination metabolic activities preceding development of the radicle and enhances seedling vigor (Taylor \& Harman, 1990 and Farooq et al., 2007). Soaking seeds contributed to rapid germination of some plants such as tomato, lettuce and lentil seeds and enhance seedling growth as presented by Ghassemi-Golezani et al. (2008), Arancon et al. (2012) and Toklu (2015). Seed germination is a critical stage in the plant development and its life cycle because the seedlings that have a vigorous growth due to hydro or osmotic priming could be able to successfully compete under wide range of conditions and consequently exhibited more yield and yield components of lentil (Koireng \& Neupane, 2014). Regarding soil health, compost tea contains microorganisms and their metabolites that acts as plant growth promoting and/or as biocontrol agents. Compost tea could be utilized in organic cultivation for enhancing plant growth by application it into the root zone or foliar application to increase the yield (Kim et al., 2015). Also, ElGizawy et al. (2013) mentioned that application of compost tea revealed increases the biological activity of soil in terms of increasing the soil total bacteria, as well as dehydrogenase activity and nitrogenase activity that increase the soil fertility.

The current study aims to evaluate the efficacy of the compost tea produced from some agricultural residues depending on particles size of compost on the germination, nodulation, growth and yield of some lentil cultivars.

\section{Materials and Methods}

\section{Experimental procedures}

Laboratory and field experiments were carried out at the laboratory of Crop Science and Experimental Farm, respectively, Faculty of Agriculture, Menoufia University, Shebin ElKom, Egypt (latitude 30 $31^{\prime} 42^{\prime}$ N, longitude $\left.31^{\circ} 04^{\prime} 08^{\prime \prime} \mathrm{E}\right)$. Such experiments aimed to study the efficiency of various compost tea derived from various agricultural residues and based on their particles size, i.e., unfractionated, relatively coarse $(>2.8 \mathrm{~mm})$ and fine $(0.6-1 \mathrm{~mm})$ on germination and seedling characters, nodulation, morphological characters, yield and quality of two lentil cultivars (Giza 4 and Family 29). Laboratory experiment was conducted on $6^{\text {th }}$ November 2017. The germination test was done using filter papers as a substrate in Petri dishes (diameter 150mm). Lentil cultivars (Giza 4 and Family 29) seeds were soaked in the various compost tea in addition to distillated water (as control) for $4 \mathrm{~h}$. Thirty primed seeds from each treatment were placed in Petri dishes for germination and incubated for 7 days under temperature $25^{\circ} \mathrm{C}$. Laboratory experiment designed in randomized complete block as a factorial trial with four replications.

Field experiment was carried out during two winter growing seasons of 2016/2017 and $2017 / 2018$. Sowing date was $5^{\text {th }}$ November in both seasons. Each experiment included twenty treatments, which were the combination of two cultivars and ten compost tea types. The treatments were arranged at random in a split plot design with three replications. Main plots were allocated for lentil cultivars (Giza 4 and Family 29), while compost tea types were assigned in sub-plots as following: 
$\mathrm{T} 0=$ Without compost tea (water as control).

$\mathrm{T} 1=$ Compost tea prepared from unfractionated bagasse compost.

$\mathrm{T} 2=$ Compost tea prepared from fraction $(>2.8 \mathrm{~mm}$ particle size) of bagasse compost.

$\mathrm{T} 3=$ Compost tea prepared from fraction $(0.6-1 \mathrm{~mm}$ particle size) of bagasse compost.

$\mathrm{T} 4=$ Compost tea prepared from unfractionated cotton stalk compost.

$\mathrm{T} 5=$ Compost tea prepared from fraction $(>2.8 \mathrm{~mm}$ particle size) of cotton stalk compost.

$\mathrm{T} 6=$ Compost tea prepared from fraction $(0.6-1 \mathrm{~mm}$ particle size) of cotton stalk compost.

$\mathrm{T} 7=$ Compost tea prepared from unfractionated rice straw compost.

$\mathrm{T} 8=$ Compost tea prepared from fraction $(>2.8 \mathrm{~mm}$ particle size) of rice straw compost.

$\mathrm{T} 9=$ Compost tea prepared from fraction $(0.6-1 \mathrm{~mm}$ particle size) of rice straw compost.

The compost tea was applied by two ways together for all treatments, as seed priming by soaking the lentil seeds in various compost tea types ( $1 \mathrm{~kg}$ seed : $0.5 \mathrm{~L}$ solution) for $4 \mathrm{~h}$ before sowing and also as foliar application at a rate of $60 \mathrm{~L} / \mathrm{fad}$ (prepared by soaking $6 \mathrm{~kg}$ mature compost into 60L distilled water), then diluted to $200 \mathrm{~L}$ water/fad and sprayed two times after 25 and 55 days after sowing (DAS). It is hypothesized that seed priming in compost extracts would contribute to rapid germination and enhance seedling growth whereas the foliar application would supply the seedling and soil with microorganisms (plant growth promoting rhizobacteria "PGPRs"), biologically active metabolites and water extractable mineral nutrients.

\section{Preparation of compost and compost tea}

Compost was prepared at Soil, Water and Environment Research Institute (SWERI), ARC, Giza, Egypt. The tested plant residues (sugarcane bagasse, cotton stalk and rice straw) after chopping were mixed with farmyard manure, rock phosphate, feldspar and bentonite at rates of $10,5,5$ and $10 \% \mathrm{w} / \mathrm{w}$, respectively. Also, vinasse solution and lignocellulosic inoculant (mixture of Trichoderma harzianum and Trichoderma viridi) were added at rates of 1 and $1 \% \mathrm{v} / \mathrm{w}$, respectively, as amendments. The compost heaps received the suitable water and turning was done every 15 days for keeping the suitable moisture and aeration along the composting process. After compost maturation (three months), the heaps were bioaugmented with a mixture of rhizobacteria inoculant (Bacillus polymyxa, Serratia mercescens and Pseudomonas fluorescens) at rate of $1 \mathrm{~L}$ per ton compost and left for curing for another 30 days (Owis et al., 2016). Composts were physically processed through dry fractionation-based particles size using sieves according to El-Tahlawy et al. (2018). In context, unfractionated compost and two fractions with particles size $>2.8$ and $0.6-1 \mathrm{~mm}$ of each compost type were applied for compost tea preparing. Table 1-a represents some physical, chemical and biological properties of applied compost.

Aerated compost tea types were prepared by steeping the mature compost packed into cotton bag and submerged into distilled water with ratio 1:10 $(\mathrm{w} / \mathrm{v})$ amended with molasses $(0.5 \%)$, ammonium nitrate $(0.5 \mathrm{~g} / \mathrm{L})$ and dipotassium phosphate $(0.5 \mathrm{~g} / \mathrm{L})$ as a microbial food source according to Hegazy et al. (2015). The systems were continuously aerated using air pumps for three days brewing cycle. The outcome compost tea types properties are shown in Table 1-b.

Soil samples were randomly taken from the depth of $0-30 \mathrm{~cm}$ from the soil surface. Samples were analyzed according to Black (1965) and Jackson (1973). The soil physical and chemical properties of both seasons are listed in Table 2-a. Monthly climatic data of experimental site during both growing seasons are listed in Table 2-b.

\section{Crop management}

In the field trial, lentil seeds were sown on $5^{\text {th }}$ November in both seasons by hand drilled in beds (width $120 \mathrm{~cm}$ ). Each bed contains 4 rows with distance between rows about $20 \mathrm{~cm}$. The area of each experimental plot was $18 \mathrm{~m}^{2}$ ( $6 \mathrm{~m}$ width $\times 3 \mathrm{~m}$ long). Empty area $(1.2 \mathrm{~m})$ was left as buffer area between all sub-plots in order to eliminate any interfere effect of foliar spray. Rhizobium inoculation was done using solid carrier of vermiculite and mixture of two Rhizobium leguminosarum strains (TAL168 and ICARDA139), were supplied by microbiology department, SWERI, ARC, Giza, Egypt, at a rate of $300 \mathrm{~g} / 35 \mathrm{~kg}$ seeds. Lentil cultivars 
seed were obtained annually from Food Legume Research Program, Field Crops Research Institute, ARC, Giza, Egypt. The plant density used under investigation was 120plants $/ \mathrm{m}^{2}$. The preceding crop was maize in both seasons. During soil preparation, all experimental treatments received superphosphate fertilizer at a rate of $100 \mathrm{~kg} / \mathrm{fad}$ $\left(15 \% \mathrm{P}_{2} \mathrm{O}_{5}\right)$ and potassium sulfate at a rate of $50 \mathrm{~kg} /$ fad $\left(48 \% \mathrm{~K}_{2} \mathrm{O}\right)$. However, nitrogen fertilizer was added at a rate of $15 \mathrm{~kg} \mathrm{~N} / \mathrm{fad}$ in the form of ammonium sulfate $(20.6 \% \mathrm{~N})$ at sowing as an activation portion.

TABLE 1-a. Some physical, chemical and biological properties of compost sources.

\begin{tabular}{|c|c|c|c|c|c|c|c|c|c|}
\hline \multirow[t]{2}{*}{ Properties } & \multicolumn{3}{|c|}{$\begin{array}{c}\text { Sugarcane bagasse } \\
\text { compost* }\end{array}$} & \multicolumn{3}{|c|}{ Cotton stalk compost* } & \multicolumn{3}{|c|}{ Rice straw compost* } \\
\hline & F0 & F1 & F2 & F0 & F1 & F2 & F0 & F1 & F2 \\
\hline $\mathrm{pH}$ & 6.23 & 6.29 & 5.71 & 7.71 & 7.73 & 7.79 & 6.53 & 6.53 & 6.32 \\
\hline $\mathrm{EC}\left(\mathrm{dS} / \mathrm{m}\right.$ at $\left.25^{\circ} \mathrm{C}\right)$ & 3.77 & 4.53 & 4.55 & 4.11 & 3.86 & 3.58 & 4.66 & 5.11 & 4.50 \\
\hline Organic matter $\%$ & 30.79 & 42.32 & 31.17 & 46.71 & 34.88 & 35.65 & 32.8 & 37.02 & 28.14 \\
\hline Total nitrogen $\%$ & 1.61 & 1.67 & 1.04 & 1.55 & 1.58 & 1.26 & 1.38 & 1.21 & 1.11 \\
\hline C/N Ratio & 10.64 & 14.10 & 16.66 & 17.04 & 12.22 & 15.77 & 13.20 & 17.06 & 14.22 \\
\hline Total phosphorus \% & 0.46 & 0.41 & 0.51 & 0.41 & 0.42 & 0.52 & 0.48 & 0.46 & 0.41 \\
\hline $\begin{array}{l}\text { Total bacteria (Log } \\
\text { No.cfu/g dry weight) }\end{array}$ & 9.20 & 10.42 & 8.60 & 14.46 & 8.32 & 10.35 & 11.22 & 10.88 & 9.90 \\
\hline $\begin{array}{l}\text { Total actinobacteria } \\
\text { (Log No.cfu/g dry } \\
\text { weight) }\end{array}$ & 8.05 & 9.12 & 7.53 & 12.65 & 7.28 & 8.39 & 9.81 & 9.52 & 8.67 \\
\hline $\begin{array}{l}\text { Total fungi (Log } \\
\text { No.cfu/g dry weight) }\end{array}$ & 5.94 & 5.82 & 5.25 & 6.00 & 5.66 & 6.10 & 6.89 & 5.16 & 7.81 \\
\hline
\end{tabular}

* F0, F1 and F2: The unfractionated, relatively coarse $(>2.8)$ and fine $(0.6-1 \mathrm{~mm})$ of compost, respectively.

TABLE 1-b. Some chemical and biological properties of produced compost tea.

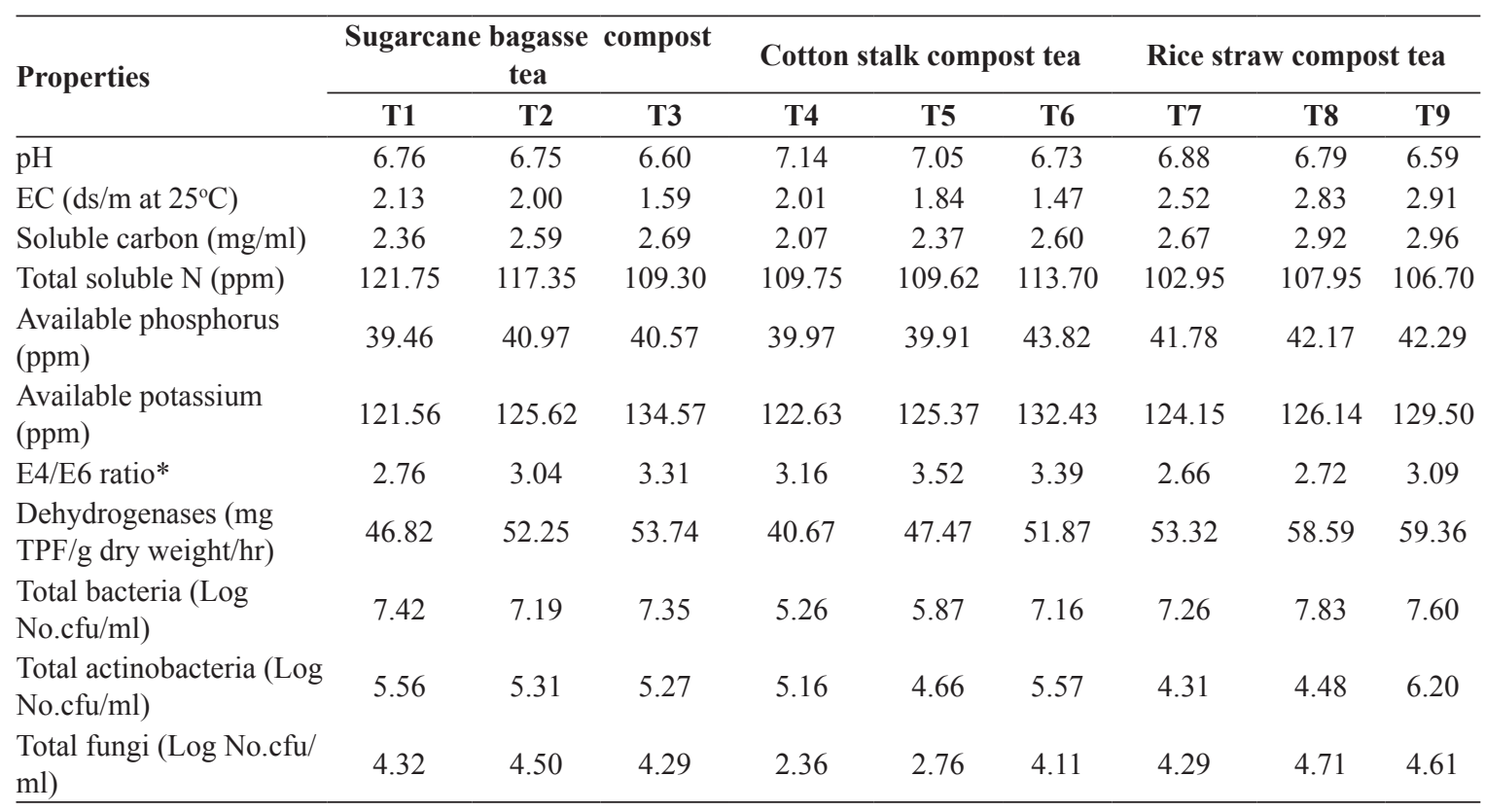

* E4/E6: Extinction coefficient 
TABLE 2-a. Physical and chemical properties of the experimental soil during both seasons.

\begin{tabular}{|c|c|c|c|c|c|c|c|c|c|c|}
\hline \multirow{2}{*}{ Properties } & \multirow{2}{*}{$\begin{array}{l}\text { Texture } \\
\text { class }\end{array}$} & \multirow{2}{*}{$\mathbf{p H}$} & \multirow{2}{*}{$\begin{array}{l}\text { E.C. } \\
\text { ds } / m\end{array}$} & \multirow{2}{*}{$\begin{array}{c}\text { O.M. } \\
\%\end{array}$} & \multicolumn{6}{|c|}{ Available nutrients (ppm) } \\
\hline & & & & & $\mathbf{N}$ & $\mathbf{P}$ & $\mathbf{K}$ & $\mathrm{Fe}$ & Zn & Mn \\
\hline $2016 / 17$ & Clay loam & 7.25 & 0.63 & 1.82 & 32.5 & 9.2 & 321.3 & 4.16 & 0.98 & 2.71 \\
\hline $2017 / 18$ & Clay loam & 7.12 & 0.61 & 1.83 & 33.6 & 9.6 & 332.4 & 4.09 & 1.04 & 2.18 \\
\hline
\end{tabular}

TABLE 2-b. Average monthly climatic data of the experimental site during growing periods of both seasons.

\begin{tabular}{|c|c|c|c|c|c|c|}
\hline \multirow{3}{*}{ Month } & \multicolumn{3}{|c|}{ 2016/2017 season } & & & $2017 / 2018$ season \\
\hline & \multicolumn{2}{|c|}{ Temperature $\left(\mathrm{C}^{\circ}\right)$} & \multirow{2}{*}{$\begin{array}{c}\text { Relative humidity } \\
(\%)\end{array}$} & \multicolumn{2}{|c|}{ Temperature $\left(\mathrm{C}^{\circ}\right)$} & \multirow{2}{*}{ Relative humidity (\%) } \\
\hline & Max. & Min. & & Max. & Min. & \\
\hline November & 24.07 & 16.10 & 56.70 & 24.33 & 15.93 & 55.45 \\
\hline December & 18.84 & 11.52 & 56.52 & 22.00 & 13.74 & 58.56 \\
\hline January & 18.26 & 9.77 & 56.71 & 19.16 & 11.84 & 55.63 \\
\hline February & 19.96 & 10.39 & 59.89 & 23.50 & 13.89 & 51.07 \\
\hline March & 23.81 & 14.84 & 52.16 & 27.84 & 16.39 & 45.89 \\
\hline April & 26.24 & 16.05 & 48.57 & 29.10 & 18.03 & 45.95 \\
\hline
\end{tabular}

\section{Plant measurements}

In lab trial, germination and seedling characters were measured at the end of germination period at laboratory during the seventh day. Final germination percentage was calculated using the followed formula:

Germination $(\%)=($ Number of final germinated seeds)/(Total number of tested seeds) $\times 100$

Shoot and radical lengths $(\mathrm{cm})$ were recorded randomly from twenty seedling. Seedling vigor index was calculated according the formula mentioned by Abdul-Baki \& Anderson (1970) as follows:

Seedling vigor index $=($ shoot length + radical length) $\times$ Germination $\%$

In field trial, nodulation status and morphological characters of the uprooted samples at the growth period (80 DAS) were assayed. Eight plants were uprooted carefully by mattock at random from each experimental plot. Lentil roots were dipped in water to remove soil then washed with distilled water. Nodulation parameters were evaluated with nodules number, nodules dry weight and nitrogenase activity. Nitrogenase enzyme activity in fresh nodulated roots was estimated using acetylene reduction assay as described by Hardy et al. (1973). The morphological characters of plants was described as plant height, number of branches/plant, shoot and root dry weight/plant and root area. The plant roots were detached and images of roots were captured with 300 dots per inch (dpi) resolution using a flatbed scanner (HP
Scanjet G2710). Root area was measured through digital image analysis as described by Lebowitz (1988).

The nutritional status of plant at 80 DAS were represented as nitrogen, phosphorus and potassium contents in shoot. A wet digestion of oven dried plant material was performed using concentrated sulphuric acid and perchloric acid as a catalyst according to Jackson (1973). Using the micro Kjeldahl method to determine total nitrogen as outlined in AOAC (2000). According to Page et al. (1982), phosphorus was determined spectrophotometrically using ammonium molybdate and stannous chloride reagents as well as potassium was determined using Flamephotometer.

Total chlorophyll in lentil leaves was estimated during the great flowering and pod formation periods (80 and 95 DAS) using chlorophyll meter SPAD 502 Plus (Minolta Co. Ltd., Osaka, Japan).

At physiological maturity stage (156 and 154 DAS in the first and second seasons, respectively), seed yield and its components, i.e., number of pods/ plant, number of seeds/plant, 1000-seed weight (g.), seed yield/plant (g.) and seed and biological yield/ fad $(\mathrm{kg})$ were estimated. The seed and biological yield/fad were determined by harvesting the central two beds from each experimental plots, then the yield converted to fad.

After drying and grinding seed samples, protein \% was calculated by multiplying nitrogen percentage by the factor 6.25 as outlined in AOAC (2000). 


\section{Statistical analysis}

Statistical analysis of data was done by the analysis of variance (ANOVA) according to Snedecor \& Cochran (1980). Multiple comparisons of treatment means were done by least significant difference test (LSD) at $\mathrm{P} \leq 0.05$ level. The analysis was performed using CoStat program, ver. 6.4, CoHort software.

\section{$\underline{\text { Results and Discussion }}$}

\section{Germination and seedling characters}

Germination and seedling traits were affected by lentil cultivars, seed priming in compost tea and their interaction (Table 3). The recorded data indicated that Giza 4 exhibited significant values above Family 29 for all germination and seedling traits except germination \%. These increases were amounted to $4.30,11.63$ and $9.29 \%$ for radical length, shoot length and seedling vigor index traits, respectively more than Family 29 cultivar. The variation in seedling traits of lentil cultivars had been shown to be affected by the genetic variability. In this concern, Foti et al. (2018) concluded that germination and early growth potential could be utilized as an active strategy to expose genetic differences in lentil genotypes. Genetic variation in shoot and root of seedling lentil were observed by Sarker et al. (2005).

Concerning compost tea effect, it is appeared from Table 3 and Fig. 1 that seed priming in compost tea prepared from compost either unfractionated or fractionated significantly increased germination $\%$, radical length, shoot length and seedling vigor index compared to seed priming in water (control). The germination and seedling traits recorded increases as the compost particles size decrease with superiority of compost tea prepared from rice straw (T9) followed by cotton stalk (T6) without significant differences in most cases. Priming seeds with compost tea had a better effect on seed germination and seedling traits. This superiority might be due to the great importance of these extractions in stimulate the physiological processes, which probably resulted in increases cell division of seedling. Preprocessing the seeds using priming technique could lead to reduction in the period of seedling formation with uniform in the plants growth. By priming, a partial hydration of seeds lead to modulation in pre-germinative metabolic activities influencing the development of seedling (McDonald, 2000). Similar results were obtained by Bijanzadeh et al. (2010) and Arancon et al.
(2012) who reported that germination percentage and seedling growth were enhanced by priming seeds in compost extracts.

The interaction between lentil cultivars and seed priming with compost tea had a significant effect on germination and seedling traits (Table 3 ). The highest significant values of germination $\%$, shoot length and seedling vigor index were observed in primed seeds of Giza 4 cultivar with compost tea prepared from finest rice straw compost. Furthermore, primed seeds of Family 29 and Giza 4 with T9 produced the longest radical. On the contrary, the lowest germination \%, radical and shoot lengths and seedling vigor index were recorded by primed seeds of Family 29 in water (without compost tea).

\section{Nodulation parameters}

Data in Table 4 shows the nodulation status of lentil plants, at $80 \mathrm{DAS}$, as an indication to the symbiotic nitrogen fixation. The nodulation status was assayed as number of nodules, dry weight of nodules and nitrogenase activity. Regarding the lentil cultivars, the obtained results revealed that Giza 4 cultivar significantly $(\mathrm{P} \leq 0.05)$ outweighed Family 29 cultivar by 29.10 and $14.17 \%$ in nodules number, 22.87 and $14.92 \%$ in nodules dry weight and 22.54 and $14.37 \%$ in nitrogenase activity during both growing seasons, respectively. The varietal differences in number and dry weight of nodules were documented by Badawi et al. (2014). Moreover, El-Hersh et al. (2011) found higher significant values of nitrogenase activity and nodules number/plant in Giza 4 cultivar more than in Giza 9 cultivar.

Regarding the effect of compost tea application, the addition of compost tea generally showed a significant $(\mathrm{P} \leq 0.05)$ improvement in the nodulation status comparing to the control treatment (without compost tea). Except for compost tea prepared from sugarcane bagasse compost, the finest particles of rice straw or cotton stalk surpassed compost tea that prepared from unfractionated compost or relatively coarse fractions for all nodulation parameters during two seasons. The data of nodulation status generally appeared the stimulation effect of compost tea that agree with Badawi et al. (2014) who attributed such stimulation to improvement in the photosynthesis process which enhance nodulation performance or to the promotive effects of promoting rhizobacteria which act to enhance root proliferation and provide more infection sites for rhizobia. 
TABLE 3. Germination \% and seedling characters of lentil cultivars as affected by various compost tea priming.

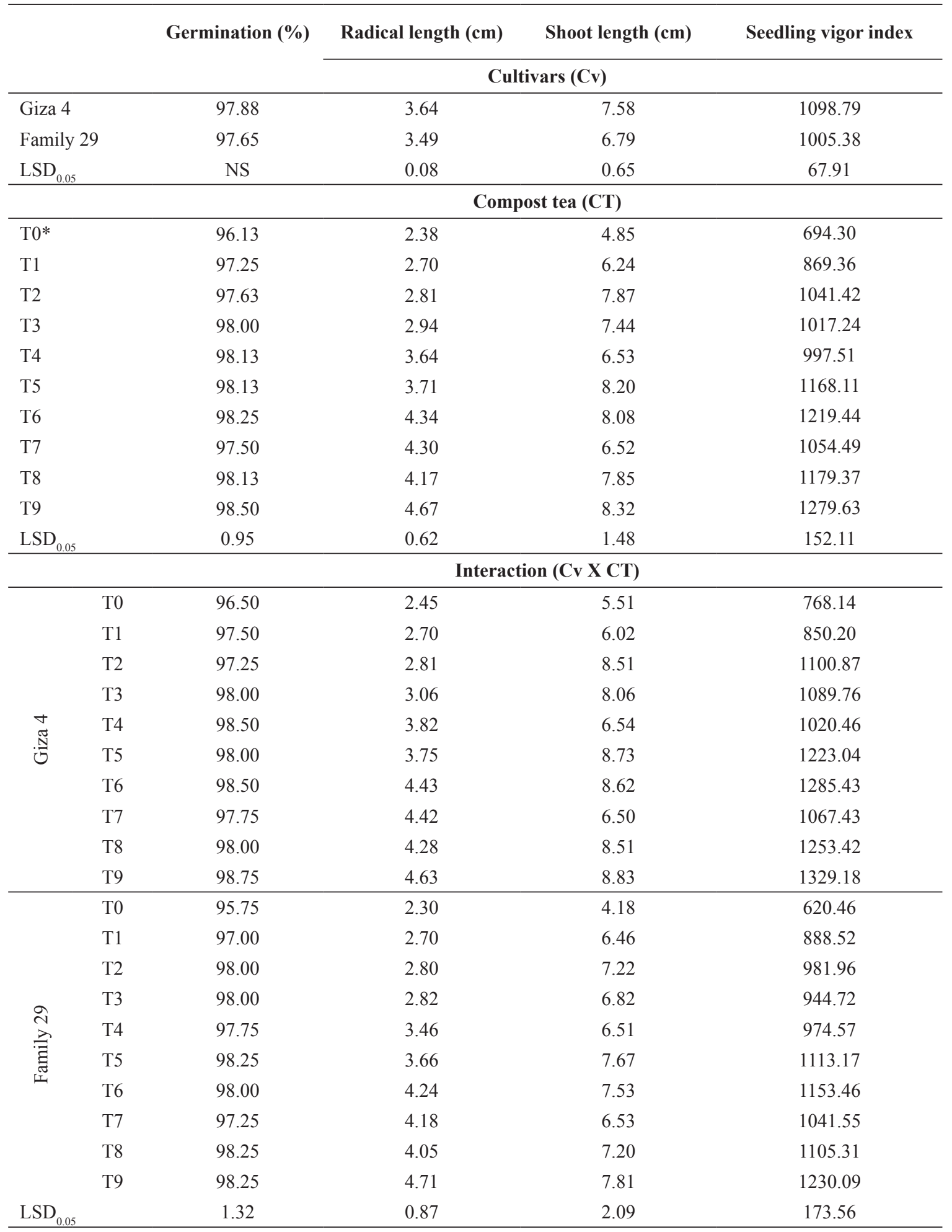

* $\mathrm{T} 0=$ Without compost tea (water), $\mathrm{T} 1=$ Compost tea from unfractionated bagasse compost, $\mathrm{T} 2=$ Compost tea from fraction $(>2.8 \mathrm{~mm}$ particle size) of bagasse compost, $\mathrm{T} 3=$ Compost tea from fraction $(0.6-1 \mathrm{~mm}$ particle size $)$ of bagasse compost, $\mathrm{T} 4=$ Compost tea from unfractionated cotton stalk compost, T5 $=$ Compost tea from fraction $(>2.8 \mathrm{~mm}$ particle size $)$ of cotton stalk compost, T6= Compost tea from fraction (0.6-1 mm particle size) of cotton stalk compost, $\mathrm{T} 7=$ Compost tea from unfractionated rice straw compost; $\mathrm{T} 8=\mathrm{Compost}$ tea prepared from fraction $(>2.8 \mathrm{~mm}$ particle size $)$ of rice straw compost and $\mathrm{T} 9=$ Compost tea from fraction $(0.6-1 \mathrm{~mm}$ particle size $)$ of rice straw compost. 


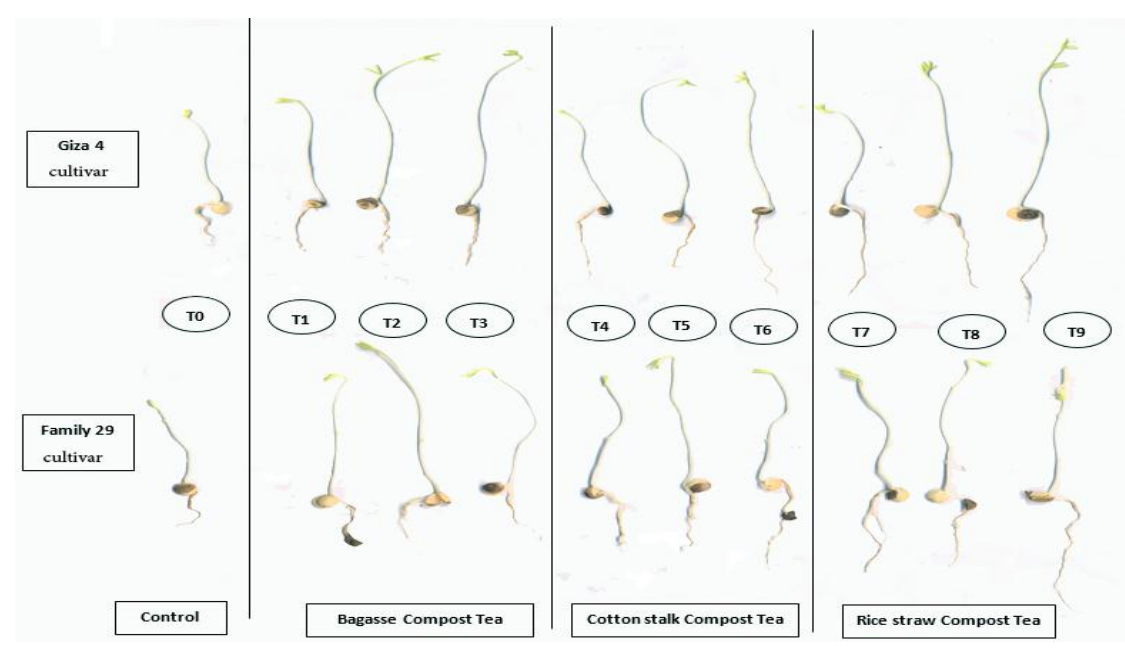

Fig. 1. Seedling characters of lentil cultivars as affected by compost tea priming.

Concerning the interaction between cultivars and the compost tea types, a significant variation $(\mathrm{P} \leq 0.05)$ was recorded. The response to various types of compost tea was depended on the lentil cultivar. Giza 4 cultivar shows higher values more than Family 29 with the compost tea prepared from finest fractions of rice straw or cotton stalk. The maximum values 33.33 and 33.67 nodule/plant, 167.76 and $178.34 \mathrm{mg} / \mathrm{plant}$ for nodule dry weight and 19.02 and $19.64 \mu \mathrm{mol} \mathrm{C}_{2} \mathrm{H}_{4} / \mathrm{g}$ d.wt. nodules $/ \mathrm{h}$ for nitrogenase activity were attained by treated Giza 4 cultivar with compost tea prepared from finest particles of rice straw compost (T9) in two seasons, respectively, compared with other tested combination. Treated the same cultivar (Giza 4) with compost tea prepared from the finest particles of cotton stalk compost (T6) recorded the next ranked without significant differences in most cases. The variation in compost raw materials and particle size may lead to a quantitative and qualitative variation in microbial or nutritional content of the produced compost tea leading to varied influence lentilRhizobium symbiotic relationship.

\section{Morphological parameters}

Data in Table 5 shows the values of morphological parameters (at 80 DAS) of lentil cultivars under the effect of various compost tea application. Regarding the varietal differences, the data shows that Giza 4 cultivar was significantly $(\mathrm{P} \leq 0.05)$ surpassed Family 29 in all parameters. The recorded increases were 6.68 and $9.99 \%$ in plant height, 10.61 and 11.11 in number of branches, 5.70 and $5.05 \%$ in shoot dry weight, 17.51 and $11.29 \%$ in root dry weight, 18.52 and $22.05 \%$ in root area in both growing seasons, respectively. The superiority of Giza 4 cultivar in the total dry weight may be attributed to the increase in its plant height, number of branches and root area (Table 5) and nodulation parameters (Table 4) which caused an increase in the amount of metabolites synthesized. Similar results were obtained by Gahoonia et al. (2006), Rizk et al. (2011), Mekkei \& El-Haggan (2013) and Choudhary et al. (2017).

Concerning the effect of compost tea, data in shows a significant $(\mathrm{P} \leq 0.05)$ predictable improvement in all morphological parameters of lentil due to the application of compost tea as compared with control. The fractionation process of compost led to produce compost tea, which causes a positive effect on all morphological characters of the growing plants. The maximum values were recorded by compost tea prepared from finest particle $(0.6-1 \mathrm{~mm})$ of cotton stalk compost followed with that produced from the rice straw of the same size. The average increases in plant height, number of branches/plant, shoot dry weight/plant, root dry weight/plant and root area/plant were 51.45 and $27.52 \%, 49.39$ and $39.30 \%, 23.36$ and $20.51 \%$, 12.15 and $10.68 \%$ and 162.25 and $161.41 \%$, respectively by application of the finest particles of cotton stalk compost tea (T6) and rice straw compost tea (T9) over the untreated plants (T0). The variation in vegetative growth due to the fractionation process of the compost used for tea preparation which potentially may cause by the variation in enzyme activities, available nutrients and/or microbial metabolites in compost tea produced (Table 1-b). The stimulation effect of compost tea on the vegetative growth of some legume crops were previously documented by other researchers such as Kim et al. (2015) and Ahmadpour \& Bahrami (2016). 
TABLE 4. Nodulation status of lentil cultivars as affected by various compost tea application.

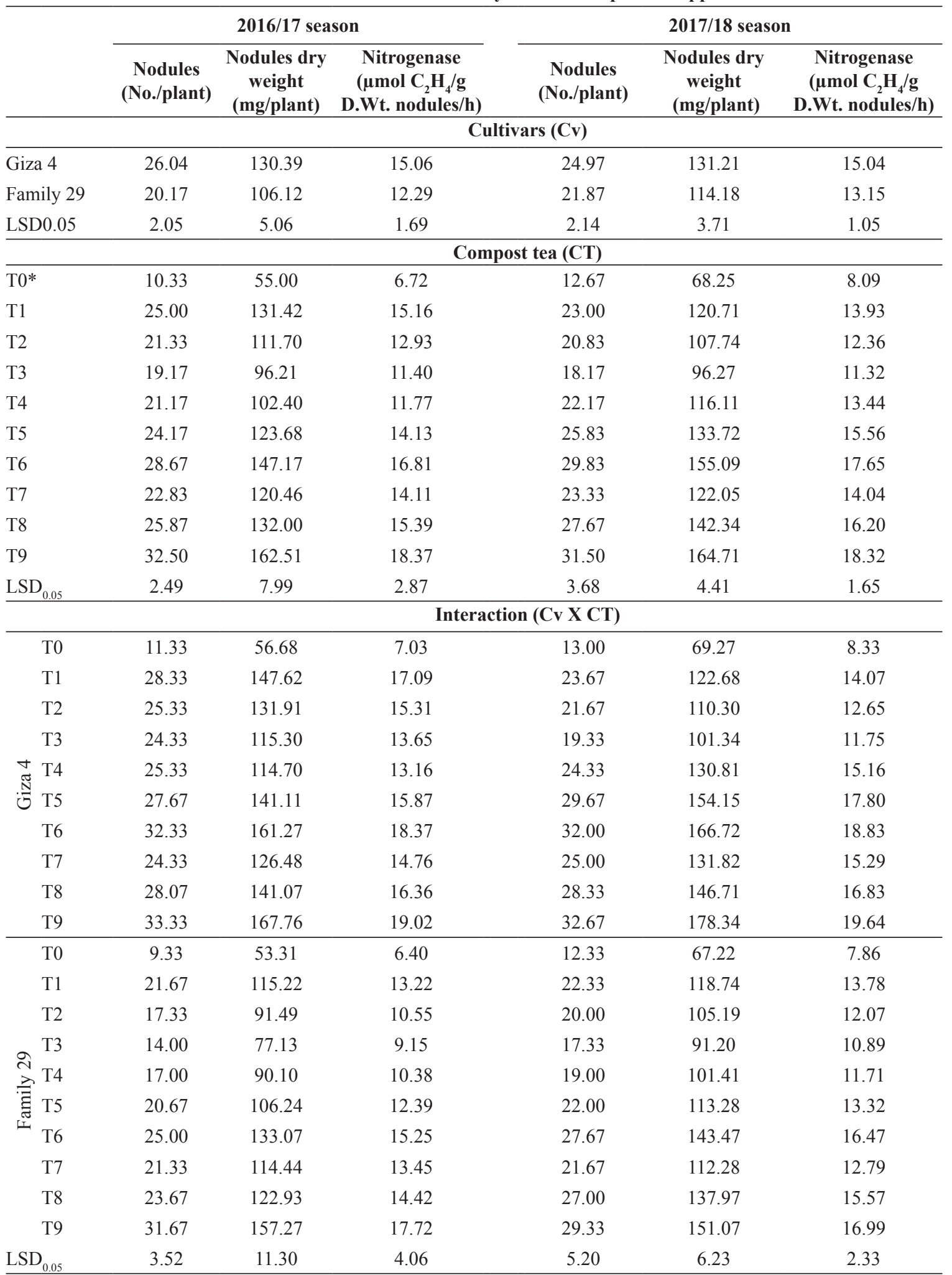

*T0 $=$ Without compost tea (water), $\mathrm{T} 1=$ Compost tea from unfractionated bagasse compost, $\mathrm{T} 2=$ Compost tea from fraction $(>2.8 \mathrm{~mm}$ particle size) of bagasse compost, $\mathrm{T} 3=$ Compost tea from fraction $(0.6-1 \mathrm{~mm}$ particle size $)$ of bagasse compost, $\mathrm{T} 4=$ Compost tea from unfractionated cotton stalk compost, T5= Compost tea from fraction $(>2.8 \mathrm{~mm}$ particle size $)$ of cotton stalk compost, T6= Compost tea from fraction $(0.6-$ $1 \mathrm{~mm}$ particle size) of cotton stalk compost, $\mathrm{T} 7=$ Compost tea from unfractionated rice straw compost, $\mathrm{T} 8=\mathrm{Compost}$ tea prepared from fraction $(>2.8 \mathrm{~mm}$ particle size) of rice straw compost and $\mathrm{T} 9=$ Compost tea from fraction (0.6-1mm particle size) of rice straw compost. 
TABLE 5. Morphological characters of lentil cultivars as affected by various compost tea application.

\begin{tabular}{|c|c|c|c|c|c|c|c|c|c|c|}
\hline & \multicolumn{5}{|c|}{ 2016/17 season } & \multicolumn{5}{|c|}{ 2017/18 season } \\
\hline & $\begin{array}{c}\text { Plant } \\
\text { height }(\mathrm{cm})\end{array}$ & $\begin{array}{l}\text { Branches } \\
\text { No./plant }\end{array}$ & $\begin{array}{c}\text { Shoot } \\
\text { D.Wt. } \\
\text { (g/plant) }\end{array}$ & $\begin{array}{c}\text { Root D.Wt. } \\
\text { (mg/plant) }\end{array}$ & $\begin{array}{c}\text { Root } \\
\text { area } \\
\left(\mathrm{cm}^{2}\right)\end{array}$ & $\begin{array}{c}\text { Plant } \\
\text { height } \\
(\mathrm{cm})\end{array}$ & $\begin{array}{l}\text { Branches } \\
\text { No./plant }\end{array}$ & $\begin{array}{l}\text { Shoot } \\
\text { D.Wt. } \\
\text { (g/plant) }\end{array}$ & $\begin{array}{c}\text { Root } \\
\text { D.Wt. } \\
\text { (mg/plant) }\end{array}$ & $\begin{array}{l}\text { Root } \\
\text { area } \\
\left(\mathrm{cm}^{2}\right)\end{array}$ \\
\hline & \multicolumn{10}{|c|}{ Cultivars (Cv) } \\
\hline Giza 4 & 38.33 & 3.65 & 2.04 & 938.4 & 3.84 & 43.94 & 4.00 & 2.08 & 975.8 & 3.93 \\
\hline Family 29 & 35.93 & 3.30 & 1.93 & 798.6 & 3.24 & 39.95 & 3.60 & 1.98 & 876.8 & 3.22 \\
\hline \multirow[t]{2}{*}{$\mathrm{LSD}_{0.05}$} & 0.19 & 0.23 & 0.01 & 30.22 & 0.24 & 0.32 & 0.34 & 0.02 & 21.05 & 0.29 \\
\hline & \multicolumn{10}{|c|}{ Compost tea (CT) } \\
\hline T0* & 29.76 & 2.75 & 1.73 & 797.8 & 1.76 & 33.35 & 3.00 & 1.78 & 870.9 & 1.79 \\
\hline $\mathrm{T} 1$ & 33.02 & 3.00 & 2.16 & 840.4 & 3.63 & 39.33 & 3.50 & 2.21 & 919.0 & 3.74 \\
\hline $\mathrm{T} 2$ & 39.07 & 3.34 & 1.95 & 865.8 & 3.15 & 41.60 & 3.75 & 1.98 & 913.2 & 3.23 \\
\hline T3 & 40.28 & 3.59 & 2.00 & 854.2 & 2.89 & 41.52 & 3.67 & 2.03 & 935.1 & 3.02 \\
\hline $\mathrm{T} 4$ & 37.33 & 3.50 & 1.88 & 880.3 & 3.44 & 42.77 & 3.84 & 1.96 & 919.9 & 3.19 \\
\hline T5 & 43.15 & 3.59 & 1.96 & 891.1 & 3.96 & 47.54 & 4.17 & 2.00 & 942.6 & 4.18 \\
\hline T6 & 46.36 & 4.09 & 2.14 & 910.8 & 4.69 & 49.22 & 4.50 & 2.19 & 960.7 & 4.62 \\
\hline $\mathrm{T} 7$ & 32.31 & 3.42 & 1.93 & 864.6 & 3.23 & 38.40 & 3.67 & 2.00 & 919.6 & 3.33 \\
\hline T8 & 33.76 & 3.67 & 1.97 & 884.7 & 4.01 & 41.55 & 3.75 & 2.04 & 930.8 & 4.04 \\
\hline T9 & 36.30 & 3.84 & 2.08 & 895.5 & 4.67 & 44.18 & 4.17 & 2.15 & 951.4 & 4.61 \\
\hline \multirow[t]{2}{*}{$\mathrm{LSD}_{0.05}$} & 0.28 & 0.35 & 0.03 & 35.25 & 0.25 & 0.39 & 0.39 & 0.06 & 26.57 & 0.37 \\
\hline & \multicolumn{10}{|c|}{ Interaction (Cv X CT) } \\
\hline T0 & 31.31 & 3.00 & 1.75 & 891.2 & 1.85 & 35.51 & 3.33 & 1.79 & 930.0 & 2.24 \\
\hline $\mathrm{T} 1$ & 35.60 & 3.33 & 2.22 & 916.6 & 3.86 & 41.83 & 3.67 & 2.26 & 981.4 & 4.09 \\
\hline $\mathrm{T} 2$ & 39.50 & 3.67 & 1.99 & 925.4 & 3.36 & 44.05 & 4.00 & 2.00 & 954.3 & 3.50 \\
\hline $\mathrm{T} 3$ & 44.15 & 3.50 & 2.09 & 912.5 & 3.04 & 42.87 & 3.67 & 2.12 & 988.6 & 3.12 \\
\hline$\underset{\mathbb{J}}{\triangleleft} \mathrm{T} 4$ & 36.40 & 3.67 & 1.92 & 942.3 & 4.07 & 45.2 & 4.00 & 2.00 & 964.7 & 3.74 \\
\hline 通 T5 & 42.00 & 3.67 & 2.03 & 960.4 & 4.08 & 49.02 & 4.33 & 2.06 & 986.9 & 4.40 \\
\hline T6 & 47.65 & 4.50 & 2.17 & 984.1 & 5.12 & 50.58 & 5.00 & 2.22 & 997.7 & 4.94 \\
\hline $\mathrm{T} 7$ & 33.92 & 3.50 & 1.97 & 930.8 & 3.40 & 39.94 & 3.67 & 2.04 & 978.5 & 3.54 \\
\hline $\mathrm{T} 8$ & 34.40 & 3.67 & 2.05 & 956.3 & 4.49 & 44.06 & 4.00 & 2.09 & 984.3 & 4.70 \\
\hline T9 & 38.37 & 4.00 & 2.17 & 964.6 & 5.13 & 46.31 & 4.33 & 2.23 & 991.7 & 5.03 \\
\hline T0 & 28.20 & 2.50 & 1.72 & 704.4 & 1.67 & 31.19 & 2.67 & 1.76 & 811.9 & 1.35 \\
\hline $\mathrm{T} 1$ & 30.43 & 2.67 & 2.11 & 764.2 & 3.40 & 36.83 & 3.33 & 2.16 & 856.5 & 3.39 \\
\hline $\mathrm{T} 2$ & 38.64 & 3.00 & 1.92 & 806.2 & 2.93 & 39.15 & 3.50 & 1.96 & 872.0 & 2.96 \\
\hline $\mathrm{T}^{\mathrm{T} 3}$ & 36.40 & 3.67 & 1.92 & 795.9 & 2.74 & 40.17 & 3.67 & 1.94 & 881.6 & 2.93 \\
\hline$\stackrel{\sim}{\sim} \mathrm{T} 4$ & 38.25 & 3.33 & 1.85 & 818.2 & 2.80 & 40.33 & 3.67 & 1.91 & 875.1 & 2.63 \\
\hline 苛 $\mathrm{T} 5$ & 44.30 & 3.50 & 1.88 & 821.8 & 3.84 & 46.06 & 4.00 & 1.93 & 898.3 & 3.95 \\
\hline T6 & 45.06 & 3.67 & 2.11 & 837.4 & 4.25 & 47.85 & 4.00 & 2.15 & 923.7 & 4.31 \\
\hline $\mathrm{T} 7$ & 30.69 & 3.33 & 1.88 & 798.3 & 3.07 & 36.86 & 3.67 & 1.96 & 860.6 & 3.12 \\
\hline $\mathrm{T} 8$ & 33.11 & 3.67 & 1.90 & 813.1 & 3.53 & 39.04 & 3.50 & 1.98 & 877.2 & 3.38 \\
\hline T9 & 34.22 & 3.67 & 2.00 & 826.3 & 4.21 & 42.04 & 4.00 & 2.07 & 911.1 & 4.19 \\
\hline $\mathrm{LSD}_{0.05}$ & 0.39 & 0.50 & 0.07 & 49.85 & 0.35 & 0.56 & 0.54 & 0.09 & 37.56 & 0.60 \\
\hline
\end{tabular}

$* \mathrm{~T} 0=$ Without compost tea (water), $\mathrm{T} 1=$ Compost tea from unfractionated bagasse compost, $\mathrm{T} 2=$ Compost tea from fraction $(>2.8 \mathrm{~mm}$ particle size $)$ of bagasse compost, $\mathrm{T} 3=$ Compost tea from fraction $(0.6-1 \mathrm{~mm}$ particle size $)$ of bagasse compost, $\mathrm{T} 4=$ Compost tea from unfractionated cotton stalk compost, $\mathrm{T} 5=$ Compost tea from fraction $(>2.8 \mathrm{~mm}$ particle size $)$ of cotton stalk compost, $\mathrm{T} 6=$ Compost tea from fraction $(0.6-$ $1 \mathrm{~mm}$ particle size) of cotton stalk compost, $\mathrm{T} 7=$ Compost tea from unfractionated rice straw compost, $\mathrm{T} 8=$ Compost tea prepared from fraction $(>2.8 \mathrm{~mm}$ particle size $)$ of rice straw compost and $\mathrm{T} 9=$ Compost tea from fraction $(0.6-1 \mathrm{~mm}$ particle size) of rice straw compost. 
Regarding the interactions between lentil cultivars and compost tea types for morphological parameters, Giza 4 cultivar positively showed a higher response to compost tea treatments than Family 29 especially with application of compost tea prepared from fine fractions of cotton stalk or rice straw more than sugarcane bagasse. On the other hand, untreated Family 29 plants recorded the lowest values of morphological parameters. The increment percentage obtained by the best interaction treatment (treated Giza 4 with T6) amounted to $65.40,83.75$, 26.15, 30.70 and 233.11 more than the lowest one (treated Family 29 cultivar with T0) for plant height, number of branches/plant, shoot dry weight/plant, root dry weight and root area, respectively as an average of both seasons. The superiority effect of compost tea obtained herein may be due to its roles in enhancing nodulation and the uptake and translocation of nutrients especially in the case of lentil cultivar that have more root area. In this concern, Badawi et al. (2014) mentioned that treated Giza 9 plants with bio-enriched compost tea at a rate of 200L/fad splitted in three equal doses was the best combination to enhance the growth characters of lentil.

\section{Nutritional status}

The data of nutritional status of plant (at 80 DAS) are presented in Table 6 as affected by cultivars, compost tea types and their interaction. Concerning the cultivars effect, shoots of Giza 4 surpassed Family 29 in NPK contents. These increases were amounted to $13.52 \%$ in nitrogen content, $18.61 \%$ in phosphorus content and $19.19 \%$ in potassium content as an average of the two growing seasons. Uptake of nutrients ( $\mathrm{P}, \mathrm{K}, \mathrm{Fe}, \mathrm{Mn}, \mathrm{Cu}, \mathrm{Zn}$ and $\mathrm{Mo}$ ) significantly differed $(\mathrm{P} \leq 0.05)$ among lentil genotypes, in favor of Barimasur 4 and Barimasur 3 genotypes that have more root hair structure (Gahoonia et al., 2006).

Regarding compost types, the results of nutritional status took the same trend of the vegetative growth and nodulation parameters in stimulation effects of compost tea and affirmed that compost tea prepared from finest particle size of cotton stalk or rice straw had a positive effect more than other unfractionated or relatively coarse fractions compost. Compost tea prepared from finest fraction of cotton stalk (T6) and rice straw (T9) revealed average increases during both seasons by 126.28 and $102.47 \%$ in nitrogen content, 105.59 and $79.61 \%$ in phosphorus content and 112.27 and $103.82 \%$ in potassium content, respectively over control (untreated plants). Furthermore, improve symbiotic nitrogen fixation as an indicator by nitrogenase activity led to increase the nitrogen content in plants treated with compost tea. Also, compost tea as a source of PGPRs which play a vital role in soil health and nutrient availability according to various studies that confirmed such roles (Fritz et al., 2012; El-Gizawy et al., 2013 and Badawi et al., 2014). In this concern, Ali (2015) pointed out that treated faba bean plants with compost tea caused significant increases in the absorption rates of nutrients.

Regarding the interaction effect, data revealed that Giza 4 treated with any compost tea type exhibited increases in nutrient NPK contents over untreated plants with superiority of compost tea produced by finest particles of cotton stalk or rice straw compost. The result of nutrition status is a reflectance to the role of compost tea which develop a root system of plants (Tables 4 and 5) and thereby improve nutrients uptake. Badawi et al. (2014) stated that treated Giza 9 with bio- enriched compost tea at a rate of 200 or 300L/fad exhibited significant increases in nutrients content per shoots more than untreated Sinaa 1 plants.

\section{Chlorophyll content}

Data illustrated in Fig. 2 referred that the tested lentil cultivars significantly varied $(\mathrm{P} \leq 0.05)$ in their chlorophyll content at 80 and 95 DAS in both seasons. Chlorophyll content was gradually increased with advanced age from 80 up to 95 DAS. The data showed that cultivar Giza 4 has a higher content of chlorophyll in their leaves at the two growth periods (35.03 and 38.18) in first season and (46.35 and 50.34 ) in second season, respectively. Kumar et al. (2012) showed significant genetic variability for chlorophyll content (SPAD value) in lentil genotypes (EC 208362, VKS 16/11, DPL 53, JL 1, and IPL 98/193). Significant increments in chlorophyll content were obtained by treated lentil plants with various compost tea compared to untreated plants (water only). Application of T6 (compost tea from fraction $0.6-1 \mathrm{~mm}$ particle size of cotton stalk) performed the highest values (37.45 and 40.87) at 80 DAS and (47.23 and 53.50) at 95 DAS. Moreover, T9 took the next rank without significant differences with T6, which recorded (36.43 and 39.43) at 80 DAS and (46.16 and 52.37) at 95 DAS in the first and second seasons, respectively. The increment in chlorophyll content due to application compost tea more than untreated plants may be due to the positive effects of compost tea for enhancing the nutrients content. Chlorophyll content was significantly correlated with nitrogen content (Bojović \& Marković, 2006). 
TABLE 6. Nutritional status of lentil cultivars as affected by various compost tea application.

\begin{tabular}{|c|c|c|c|c|c|c|c|}
\hline & \multicolumn{3}{|c|}{ 2016/17 season } & \multicolumn{3}{|c|}{ 2017/18 season } \\
\hline & & $\begin{array}{c}\text { Nitrogen } \\
\text { content } \\
\text { (mg/plant) }\end{array}$ & $\begin{array}{c}\text { Phosphorus } \\
\text { content } \\
\text { (mg/plant) }\end{array}$ & $\begin{array}{c}\text { Potassium } \\
\text { content } \\
\text { (mg/plant) }\end{array}$ & $\begin{array}{c}\text { Nitrogen } \\
\text { content } \\
\text { (mg/plant) }\end{array}$ & $\begin{array}{c}\text { Phosphorus } \\
\text { content } \\
\text { (mg/plant) }\end{array}$ & $\begin{array}{c}\text { Potassium } \\
\text { content } \\
\text { (mg/plant) }\end{array}$ \\
\hline & & \multicolumn{6}{|c|}{ Cultivars (Cv) } \\
\hline \multicolumn{2}{|c|}{ Giza 4} & 61.84 & 20.80 & 72.61 & 63.75 & 21.72 & 71.89 \\
\hline \multicolumn{2}{|c|}{ Family 29} & 54.40 & 17.08 & 59.87 & 56.23 & 18.77 & 61.36 \\
\hline \multirow{2}{*}{\multicolumn{2}{|c|}{$\mathrm{LSD}_{0.05}$}} & 2.10 & 1.15 & 3.27 & 3.33 & 1.44 & 2.29 \\
\hline & & \multicolumn{6}{|c|}{ Compost tea (CT) } \\
\hline \multicolumn{2}{|l|}{$\mathrm{T} 0 *$} & 32.77 & 12.19 & 37.93 & 37.32 & 13.22 & 41.03 \\
\hline \multicolumn{2}{|l|}{$\mathrm{T} 1$} & 65.46 & 21.16 & 74.48 & 63.83 & 20.25 & 70.53 \\
\hline \multicolumn{2}{|l|}{$\mathrm{T} 2$} & 49.74 & 18.62 & 62.83 & 53.89 & 19.54 & 66.25 \\
\hline \multicolumn{2}{|l|}{$\mathrm{T} 3$} & 45.48 & 15.99 & 55.45 & 48.83 & 14.72 & 54.82 \\
\hline \multicolumn{2}{|l|}{$\mathrm{T} 4$} & 54.99 & 17.36 & 57.81 & 58.39 & 19.41 & 63.11 \\
\hline \multicolumn{2}{|l|}{ T5 } & 63.91 & 20.37 & 68.45 & 61.67 & 24.24 & 71.80 \\
\hline \multicolumn{2}{|l|}{ T6 } & 77.68 & 25.86 & 85.11 & 80.92 & 26.38 & 82.50 \\
\hline \multicolumn{2}{|l|}{$\mathrm{T} 7$} & 54.10 & 16.26 & 64.12 & 57.77 & 18.49 & 65.93 \\
\hline \multicolumn{2}{|l|}{$\mathrm{T} 8$} & 65.79 & 19.74 & 73.87 & 66.68 & 22.40 & 71.74 \\
\hline \multicolumn{2}{|l|}{ T9 } & 71.27 & 21.84 & 82.36 & 70.64 & 23.80 & 78.58 \\
\hline \multirow{2}{*}{\multicolumn{2}{|c|}{$\mathrm{LSD}_{0.05}$}} & 4.38 & 3.50 & 3.38 & 3.95 & 2.84 & 3.71 \\
\hline & & \multicolumn{6}{|c|}{ Interaction (Cv X CT) } \\
\hline \multirow{10}{*}{$\begin{array}{l}\stackrel{\nabla}{\mathbb{N}} \\
\dot{\sim}\end{array}$} & T0 & 35.04 & 12.62 & 39.45 & 38.93 & 14.24 & 43.13 \\
\hline & $\mathrm{T} 1$ & 72.79 & 23.10 & 80.37 & 71.57 & 21.68 & 77.72 \\
\hline & $\mathrm{T} 2$ & 52.19 & 20.75 & 71.26 & 55.71 & 21.13 & 73.74 \\
\hline & T3 & 47.53 & 17.43 & 60.56 & 49.69 & 15.76 & 56.92 \\
\hline & $\mathrm{T} 4$ & 57.54 & 19.58 & 64.26 & 60.75 & 20.86 & 68.25 \\
\hline & $\mathrm{T} 5$ & 66.53 & 22.46 & 76.36 & 63.75 & 25.78 & 75.09 \\
\hline & T6 & 83.15 & 28.52 & 94.63 & 87.06 & 27.81 & 91.28 \\
\hline & $\mathrm{T} 7$ & 58.12 & 18.17 & 71.37 & 62.02 & 19.93 & 68.67 \\
\hline & $\mathrm{T} 8$ & 70.08 & 21.16 & 80.48 & 73.55 & 23.89 & 78.35 \\
\hline & T9 & 75.44 & 24.23 & 87.31 & 74.49 & 26.07 & 85.78 \\
\hline \multirow{10}{*}{ 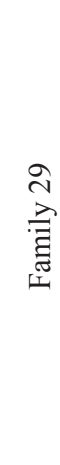 } & T0 & 30.51 & 11.76 & 36.40 & 35.71 & 12.2 & 38.92 \\
\hline & $\mathrm{T} 1$ & 58.13 & 19.22 & 68.58 & 56.08 & 18.82 & 63.33 \\
\hline & $\mathrm{T} 2$ & 47.28 & 16.50 & 54.39 & 52.06 & 17.94 & 58.75 \\
\hline & $\mathrm{T} 3$ & 43.43 & 14.54 & 50.34 & 47.96 & 13.67 & 52.72 \\
\hline & $\mathrm{T} 4$ & 52.43 & 15.14 & 51.36 & 56.02 & 17.95 & 57.97 \\
\hline & T5 & 61.29 & 18.29 & 60.54 & 59.58 & 22.69 & 68.51 \\
\hline & T6 & 72.22 & 23.20 & 75.59 & 74.78 & 24.94 & 73.71 \\
\hline & $\mathrm{T} 7$ & 50.08 & 14.34 & 56.87 & 53.52 & 17.04 & 63.19 \\
\hline & $\mathrm{T} 8$ & 61.50 & 18.31 & 67.25 & 59.80 & 20.91 & 65.12 \\
\hline & T9 & 67.09 & 19.45 & 77.40 & 66.78 & 21.53 & 71.37 \\
\hline \multicolumn{2}{|c|}{$\mathrm{LSD}_{005}$} & 6.20 & 4.95 & 4.78 & 5.86 & 4.02 & 5.25 \\
\hline
\end{tabular}

$* \mathrm{~T} 0=$ Without compost tea (water), $\mathrm{T} 1=$ Compost tea from unfractionated bagasse compost, $\mathrm{T} 2=$ Compost tea from fraction $(>2.8 \mathrm{~mm}$ particle size) of bagasse compost, $\mathrm{T} 3=$ Compost tea from fraction $(0.6-1 \mathrm{~mm}$ particle size) of bagasse compost, T4= Compost tea from unfractionated cotton stalk compost, $\mathrm{T} 5=$ Compost tea from fraction $(>2.8 \mathrm{~mm}$ particle size $)$ of cotton stalk compost, T6 $=$ Compost tea from fraction $(0.6-1 \mathrm{~mm}$ particle size $)$ of cotton stalk compost, $\mathrm{T} 7=$ Compost tea from unfractionated rice straw compost, $\mathrm{T} 8=\mathrm{Compost}$ tea prepared from fraction $(>2.8 \mathrm{~mm}$ particle size $)$ of rice straw compost and $\mathrm{T} 9=$ Compost tea from fraction $(0.6-1 \mathrm{~mm}$ particle size $)$ of rice straw compost. 

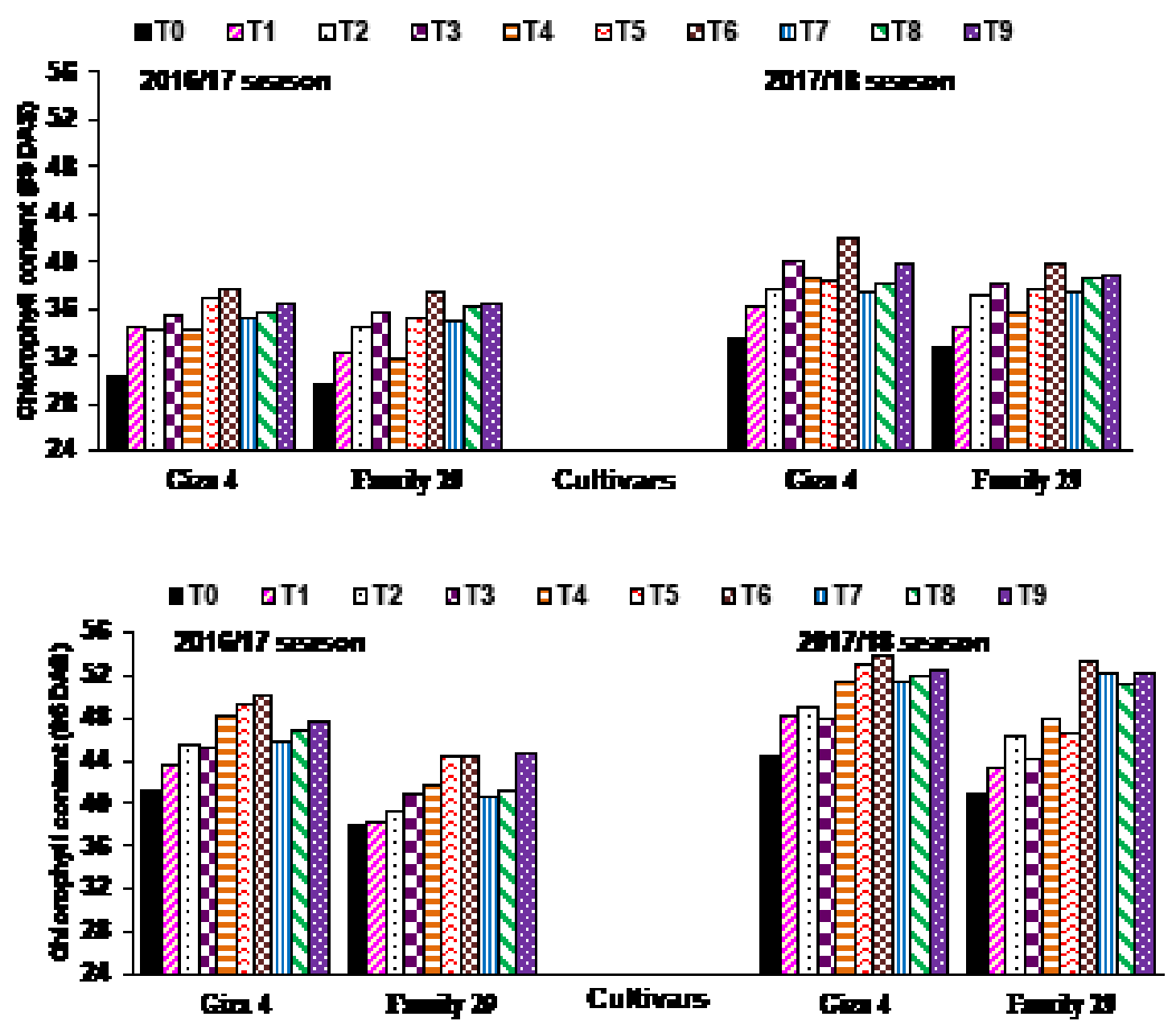

Fig. 2. Chlorophyll content of lentil cultivars as affected by compost tea application.

Effect of compost tea is dependable on lentil cultivars. It can be observed that the highest significant values of total chlorophyll were obtained when treated plants of Giza 4 cultivar with T6 which recorded (37.55 and 42.02$)$ at 80 DAS and (50.13 and 53.74) at 95 DAS in the first and second seasons, respectively. On the other side, the lowest values (29.55 and 34.45) at 80 DAS and (37.80 and 40.87) at 95 DAS in the first and second seasons, respectively were achieved by untreated plants of Family 29 cultivar. This indicated that high pigments activity was produced and hence more photosynthetic activity was appeared by treated Giza 4 with compost tea prepared from finest fraction of cotton stalk.

\section{Yield and its components}

The average performance data of two lentil cultivars for yield characters studied are presented in Table 7. The data showed that the tested cultivars significantly differed. Giza 4 cultivar produced the highest significant values of numbers of pods and seeds/plant, seed index, seed yield/plant and seed and biological yields/ fad over than Family 29 cultivar. These increases were amounted to 16.64 and $11.65 \%$ for number of pods/plant, 19.95 and $14.66 \%$ for number of seeds/plant, 19.36 and $11.30 \%$ for seed yield/ fad in the first and second seasons, respectively. The superiority of Giza 4 cultivar may be due to the raising in its number of nodules, nodules weights, nitrogenase activity and NPK contents. In this concern, Katerji et al. (2001), Mekkei \& El-Haggan (2013) and Biçer et al. (2018) found variation among lentil varieties in their seed yield and its components.

Significant differences $\quad(\mathrm{P} \leq 0.05) \quad$ were 
detected in yield and its components by application of various compost tea in both seasons (Table 7). The positive effects were observed by application of cotton stalk followed by rice straw. However, bagasse took the next rank. Compost tea application resulted in superior seed yield/ fad in terms of numbers of pods and seeds/ plant, seed index, seed yield/plant than untreated treatment. Generally, yield and its components were significantly increased with fine fraction (0.6-1 mm particle size) much than those of the fraction $(>2.8 \mathrm{~mm}$ particle size $)$ or unfractionated compost. As an average of the two seasons, the increases in seed yield and biological yield/ fad obtained from application of compost tea prepared from cotton stalk (T6) were amounted to 45.29 and $35.17 \%$ and reached by application of rice straw (T9) about 41.55 and $38.83 \%$, respectively more than untreated plants (control treatment). The positive effect of compost tea on yield and its components may be attributed to its beneficial effects on seedling characters and during vegetative growth through enhancing nodulation, photosynthesis and nutrients uptakes. In this context, Badawi et al. (2014), Ali (2015) and Toklu (2015) obtained similar results.

The interaction between cultivars and compost tea application had significant effect on yield and its components. The data showed that treated Giza 4 plants with compost tea from fraction $(0.6-1 \mathrm{~mm}$ particle size) of cotton stalk (T6) or compost tea from fraction (0.6$1 \mathrm{~mm}$ particle size) of rice straw (T9) were the best combination for achieving maximum yield and its components in the two seasons. As an average of both seasons, it can be noticed that these combination treatments caused increases amounted to 61.17 and $58.49 \%$ for seed yield/fad, 48.37 and $57.19 \%$ for biological yield more than untreated Family 29 cultivar plants, respectively. These increases might be explained on the basis of the increases in the number of branches/ plant and shoots dry weight and consequently increase the photosynthesis surface where more photosynthates were available to increase pod setting and hence seed yield/plant. From these results, it could be concluded that the application of the previous combined treatments (treated Giza 4 with T6 or T9) may be recommended for promoting the plant growth characteristics and yield. In this concern, Badawi et al. (2014) mentioned that treated Giza 9 plants with bioenriched compost tea at a rate of $200 \mathrm{~L} / \mathrm{fad}$ was the best combination to enhance the yield and its components of lentil.

\section{Protein \%}

Seed protein percentage was significantly affected by both cultivars and compost tea application as well as their interaction. Data depicted in Fig. 3 showed that the plants of Giza 4 cultivar produced the highest significant value of protein (27.72 and 28.19\%) than Family 29 in both seasons, respectively.

The data showed increases in protein percentage when the tested compost tea were applied in favor of T6 (29.64 and 29.67\%) followed by T9 (29.56 and 29.28\%) without significant differences between them which produced the highest increases than the other compost tea types and untreated plants. Similar trend was obtained by Ali (2015).

Interaction data depicted in Fig. 3 shows that Giza 4 cultivar surpassed Family 29 in the protein percentage when their plants were applied with the finest compost tea $(0.6-1 \mathrm{~mm}$ particle size) T6 or T9 which produced the highest protein (30.57 and $30.02 \%$ ) as an average of the two seasons, respectively. The stimulating effect of these combinations in increasing the protein \% may be mainly due to their roles in enhancing nodulation parameters (Table 4) and nitrogen percentage in shoot (Table 6).

\section{Conclusion}

The obtained results showed the importance of recycling agricultural residues. Application of compost tea can be efficient organic fertilizer that maximizes lentil yield. The response of lentil was significantly differed by various cultivars. The combinations between Giza 4 cultivar and compost tea produced from fractions of small particles size $(0.6-1 \mathrm{~mm})$ of cotton stalk or rice straw was found to be the best combination treatment for maximize lentil productivity under study conditions. This fractionation of compost based on particle size could be activated as a perfect practice for enhancing compost tea produced and this will in turn plant growth and yield improving. Therefore, it is necessary for further studies on compost fractionation of many various compost materials based on particles size to produce compost tea with specific characters more suitable for different crops. 
TABLE 7. Yield and its components of lentil cultivars as affected by various compost tea application.

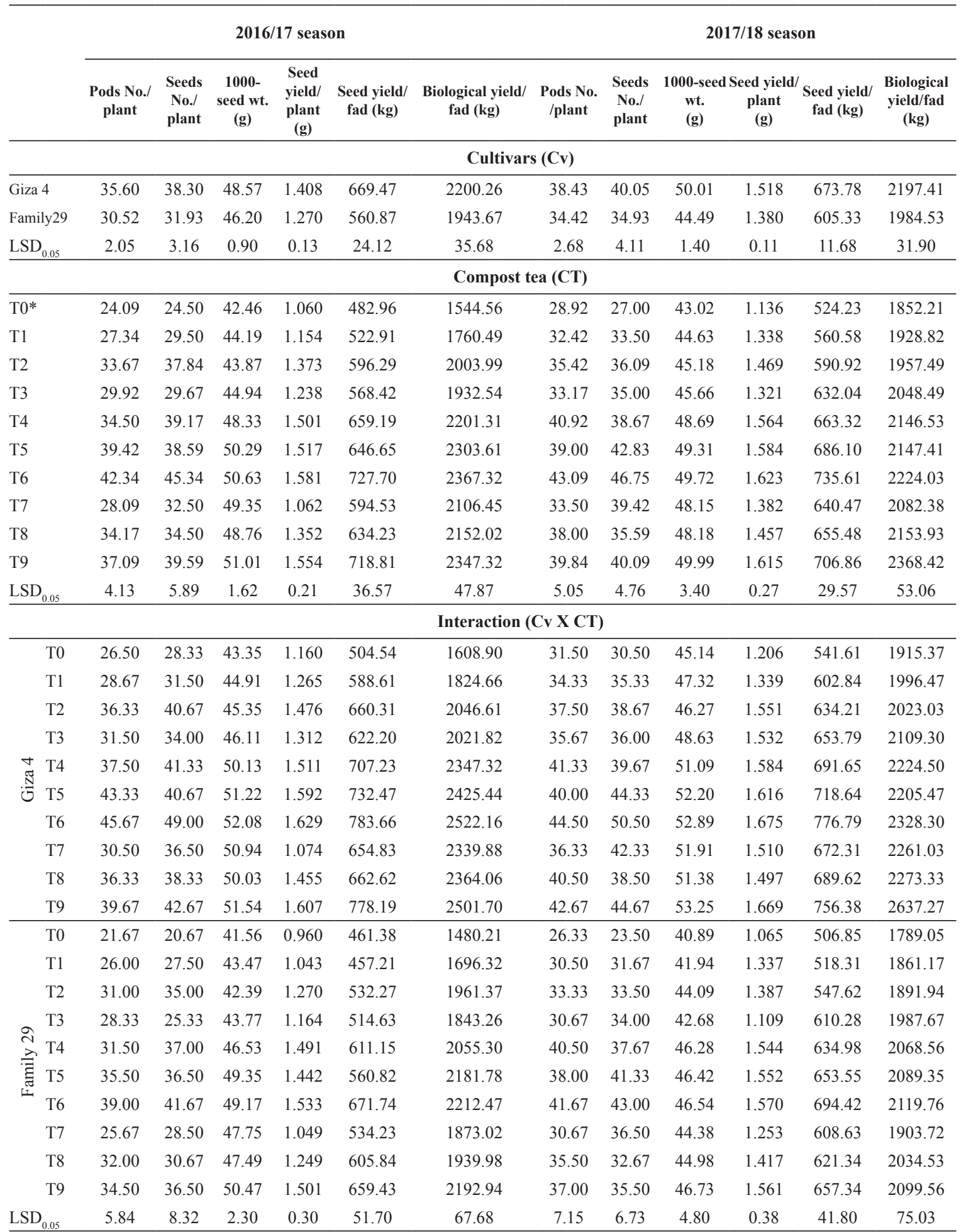

*T0 $=$ Without compost tea (water), T1= Compost tea from unfractionated bagasse compost, $\mathrm{T} 2=$ Compost tea from fraction $(>2.8 \mathrm{~mm}$ particle size) of bagasse compost, T3= Compost tea from fraction $(0.6-1 \mathrm{~mm}$ particle size) of bagasse compost, T4= Compost tea from unfractionated cotton stalk compost, $\mathrm{T} 5=$ Compost tea from fraction $(>2.8 \mathrm{~mm}$ particle size $)$ of cotton stalk compost, $\mathrm{T} 6=\mathrm{Compost}$ tea from fraction $(0.6-1 \mathrm{~mm}$ particle size $)$ of cotton stalk compost, $\mathrm{T} 7=$ Compost tea from unfractionated rice straw compost, $\mathrm{T} 8=\mathrm{Compost}$ tea prepared from fraction $(>2.8 \mathrm{~mm}$ particle size $)$ of rice straw compost and $\mathrm{T} 9=$ Compost tea from fraction $(0.6-1 \mathrm{~mm}$ particle size $)$ of rice straw compost. 


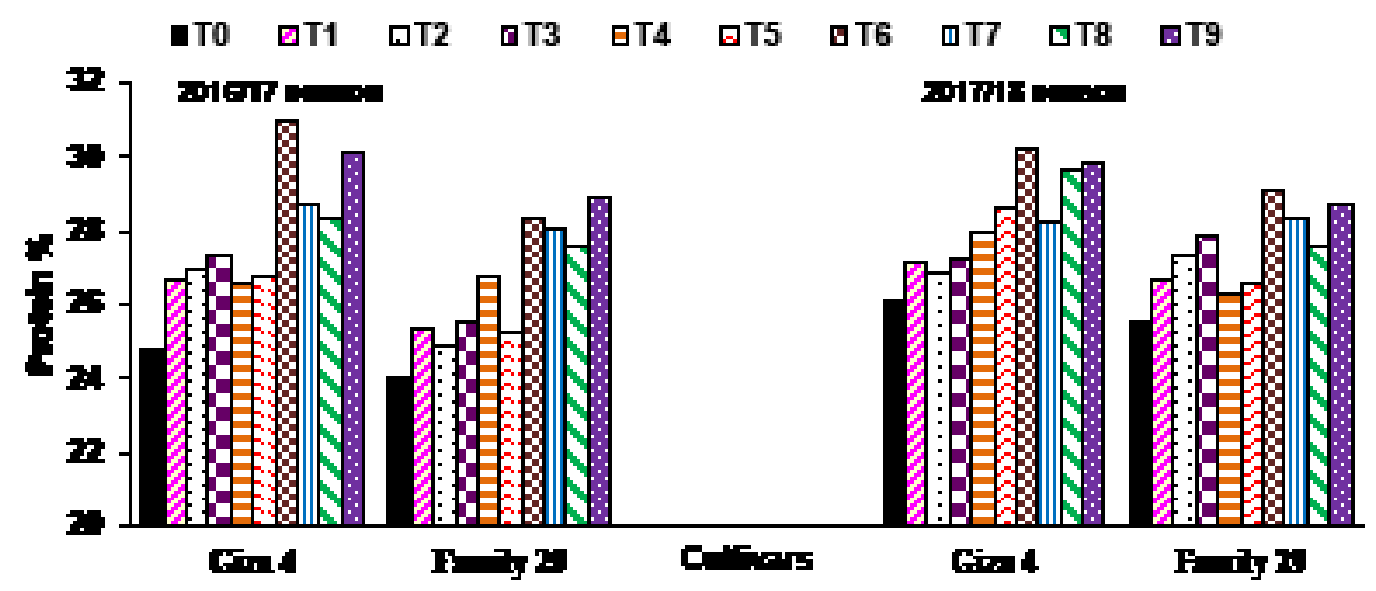

Fig. 3. Protein percentage of lentil seed cultivars as affected by compost tea application.

\section{$\underline{\text { References }}$}

Abbeddou, S., Rihawi S., Hess, H.D., Iñiguez, L., Mayer, A.C. and Kreuzer, M. (2011) Nutritional composition of lentil straw, vetch hay, olive leaves and saltbush leaves and their digestibility as measured in fat-tailed sheep. Small Ruminant Research, 96, 126-135.

Abdul-Baki, A.A. and Anderson, J.D. (1970) Viability and leaching of sugars from germinating barley. Crop Sci. 10, 31-34.

Ahmadpour, R. and Bahrami, T. (2016) Influence foliar application of compost tea under water deficit stress of lentil plant by assessment of morphological parameters. Iranian Journal of Plant Physiology and Biochemistary, 1, 40-51.

Ali, O.A.M (2015) Role of humic substances and compost tea in improvement of endogenous hormones content, flowering and yield and its components of faba bean (Vicia faba L.). Annals of Agricultural Science, Moshtohor, 53, 373-384.

AOAC (2000) "Official Methods of Analysis of the Association of Official Analytical Chemist", $17^{\text {th }} \mathrm{ed}$. Washington, D.C., USA.

Arancon, N.Q., Pant, A., Radovich, T. and Hue, N.V. (2012) Seed germination and seedling growth of tomato and lettuce as affected by vermicompost water extracts (tea). Hort. Science, 47, 1722-1728.

Badawi, F.S.F., Desoky, A.H. and Selim, T. (2014) Response of two lentil varieties to bio-enriched compost tea. Nature and Science, 12, 119-130.
Biçer, B.T., Kizilgeci, F., Albayrak, O., Akinci, C. and Yildirim, M. (2018) Stability parameters in lentil genotypes. El-Cezerî Journal of Science and Engineering, 5(2), 287-291.

Bijanzadeh, E., Nosrati, K. and Egan, T. (2010) Influence of seed priming techniques on germination and emergence of rapeseed (Brassica napus L.). Seed Science and Technology, 38(1), 242-247.

Black, C.A. (1965) "Methods of Soil Analysis", Part II. Amer. Soc. Agro. Madison, Wisconsin, USA.

Bojović, B. and Marković, A. (2006) Correlation between nitrogen and chlorophyll content in wheat (Triticum aestivum L.). Kragujevac J. Sci. 31, 69-74.

Casado, G.I.G. and González de Molina, M. (2009) Preindustrial agriculture versus organic agriculture. Land Use Policy, 26, 502-510.

Choudhary, R., Verma, S.K., Panwar, R.K., Chourasiya, V.K. and Pandey, D. (2017) Morphological characterization of lentil (Lens culinaris Medikus.) Varieties based on six qualitative traits. Journal of Pharmacognosy and Phytochemistry, 6, 1611-1615.

Cokkizgin, A. and Shtaya, M.J.Y. (2013) Lentil: Origin, cultivation techniques, utilization and advances in transformation. Agricultural Science, 1, 55-62.

Elfeki, M., Elbestawy, Ebtesam and Tkadlec, E. (2017) Bioconversion of Egypt's agricultural wastes into biogas and compost. Pol. J. Environ. Stud. 26(6), 2445-2453. 
El-Gizawy, E.S.A., Atwa, A.A.I., Talha, N.I. and Mostafa, R.A.I. (2013) Effect of compost and compost tea application on faba bean crop and some soil biological and chemical properties. J. Soil Sci. and Agric. Eng., Mansoura Univ. 4, 863-874.

El-Hersh, M.S., Abd El-Hai, K.M. and Ghanem, K.M. (2011) Efficiency of molybdenum and cobalt elements on the lentil pathogens and nitrogen fixation. Asian Journal of Plant Pathology, 5, 102-114.

El-Shimi, S.A. (2016) "The Biological Technics for Recycle Agriculture wastes. Project: Bioconversion of Agricultural Residues into Compost for Improving Crop Productivity and Environmental Protection", Soils, Water and Environment Research Institute (SWERI), Egypt.

El-Tahlawy, Y.A., Serry, Soad Y. and El-Egemey, Hend M. (2018) Characterization of compost grades originated by dry fractionation for various particle size of compost produced by some agriculture residues. Menoufia J. Soil Sci. 3, 37-51.

FAOSTAT (2017) The Food and Agriculture Organization (FAO). http://www.fao.org/faostat/en/\#data/QC.

Farooq, M., Basra, S.M.A. and Wahid, A. (2007) Improving the performance of transplanted rice by seed priming. Plant Growth Regul. 51, 129-137.

Foti, C., Khah, E.M. and Pavli, O.I. (2018) Germination profiling of lentil genotypes subjected to salinity stress. Plant Biology (Stuttg), 26, 1-7.

Fritz, J.I., Franke-Whittle, I.H., Haindl, S., Insam, H. and Braun, R. (2012) Microbiological community analysis of vermicompost tea and its influence on the growth of vegetables and cereals. Can J. Microbiol. 58, 836-847.

Gahoonia, T.S., Ali, O., Sarker, A., Nielsen, N.E. and Rahman, M.M. (2006) Genetic variation in root traits and nutrient acquisition of lentil genotypes. Journal of Plant Nutrition, 29(4), 643- 655.

Ghassemi-Golezani, K., Aliloo, A.A., Valizadeh, M. and Moghaddam, M. (2008) Effects of different priming techniques on seed invigoration and seedling establishment of lentil (Lens culinaris Medik). Journal of Food, Agriculture \& Environment, 6(2), 222-226.
Hardy, R.W.F., Burns, R.C. and Holsten, R.D. (1973) Applications of the acetylene-ethylene assay for measurement of nitrogen fixation. Soil Biology and Biochemistry, 5, 47-81.

Hegazy, M.I., Hussein, E.I. and Ali, S.A. (2015) Improving physico-chemical and microbiological quality of compost tea using different treatments during extraction. African Journal of Microbiology Research, 9, 763-770.

Hussein, S.D.A. and Sawan, O.M. (2010) The utilization of agricultural waste as one of the environmental issues in Egypt (A case study). J. App. Sci. Res. 6, 1116-1124.

Jackson, M.L. (1973) "Soil Chemical Analysis", pp. $25-$ 214. Prentice-Hall of India Private Limited, New Delhi, .

Kapoor, A., Pandit, M. and Ametha, M. (2015) Organic agriculture: Biofertilizer - A review. International Journal of Pharmaceutical \& Biological Archives, 5, 1-5.

Katerji, N., van Hoorn, J.W., Hamdy, A., Mastrorilli, M., Oweis, T. and Erskine, W. (2001) Response of two varieties of lentil to soil salanity. Agricultural Water Management, 47, 179-190.

Kim, M.J., Shim, C.K., Kim, Y.K., Hong, S.J., Park, J.H., Han, E.J., Kim, J.H. and Kim, S.C. (2015) Effect of aerated compost tea on the growth promotion of lettuce, soybean, and sweet corn in organic cultivation. Plant Pathol. J. 31, 259-268.

Koireng, R.g. and Neupane, M.B. (2014) Seed invigoration and yield of lentil (Lens culinaris Medikus) through seed priming under different seeding rates. Environment \& Ecology, 32(2), 527531.

Kumar, J., Basu, P.S., Srivastava, E., Chaturvedi, S.K., Nadarajan, N. and Kumar, S. (2012) Phenotyping of traits imparting drought tolerance in lentil. Crop and Pasture Sci. 63, 547-554.

Lairon, D. (2010) Nutritional quality and safety of organic food. A review. Agronomy for Sustainable Development, 30, 33-41.

Lebowitz, R.J.(1988) Digital image analysis measurement of root length and diameter. Environmental and Experimental Botany, 28(3), 267273. 
McDonald, M.B. (2000) Seed priming. In: "Seed Technology and Its Biological Basis", pp. 287-325, M. Black and J.D. Bewley (Ed.). Sheffield, UK: Sheffield Academic Press.

Mekkei, M.E.R. and El-Haggan, Eman A.M. (2013) Response of some lentil genotypes to nitrogen fertilization and rhizobium inoculation. Egypt. J. Plant Breed. 17(4), 1-11.

Mitiku, G. (2016) Review on agronomic practices for improving production and productivity of lentil in Ethiopia. Journal of Biology, Agriculture and Healthcare, 6, 102-106.

Owis, Amal S., El-Etr, Wafaa M., Badawi, F.S.F., Abo El-Soud, A.A. and Abdel-Wahab, A.F.M. (2016) Bio-processing the crop residues with different amendments for producing high quality compost. Inter. J. Chem.Tech. Res. 9, 43-54.

Page, A.L., Miller, R.H. and Keeney, D.R. (1982) "Methods of Soil Analysis. Part 2. Chemical and Microbiological Properties", pp. 595-624. American Society of Agronomy, Madison Wisconsin. USA.

Rizk, A.M.A., Desoky, A.H., Badawi, F.Sh.F. and Morsy, A.R. (2011) Response of two lentil varieties to coinoculation with Rhizobium and rhizobacteria in calcareous soil. Egypt. J. Appl. Sci. 26, 265-283.

Roy, F., Boye, J.I. and Simpson, B.K. (2010) Bioactive proteins and peptides in pulse crops: Pea, chickpea and lentil. Food Research International, 43, 432-442.

Sarker, A., Erskine, W. and Singh, M. (2005) Variation in shoot and root characteristics and their association with drought tolerance in lentil landraces. Genet. Res. Crop Evol. 52, 89-97.

Schrama, M., de Haan, J.J., Kroonen, M., Verstegen, H. and Van der Putten, W.H. (2018) Crop yield gap and stability in organic and conventional farming systems. Agriculture, Ecosystems \& Environment, 256, 123-130.

Snedecor, G.W. and Cochran, W.G. (1980) "Statistical Methods", $7^{\text {th }}$ ed. The Iowa State Univ. Press, Ames. Iowa, USA.

Suja, G., Byju, G., Jyothi, A.N., Veena, S.S. and Sreekumar, J. (2017) Yield, quality and soil health under organic vs conventional farming in taro. Scientia Horticulturae, 218, 334-343.

Taylor, A.G. and Harman G.E. (1990) Concepts and technologies of selected seed treatments. Ann. Rev. Phytopathol. 28, 321-339.

Toklu, F. (2015) Effects of different priming treatments on seed germination properties, yield components and grain yield of lentil (Lens culinaris Medik.). Not. Bot. Horti. Agrobo. 43(1), 153-158.

Yadav, S.S., McNeil, D.L. and Philip, C.S. (2007) "Lentil: An Ancient Crop for Modern Times". Dordrecht, The Netherlands: Springer.

(Received 18/10/2018

accepted 21/11/2018) 


\section{تأثير إضافة أنواع مختلفة من شاي الكمبوست على الإنبات وتكوين العقد الجذرية والصفات

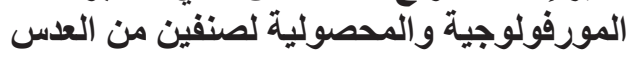

أسامه على محمد على(1)، ياسر عربي الطحلاوي(2) و شبل عبد الله عبد الجواد(2)

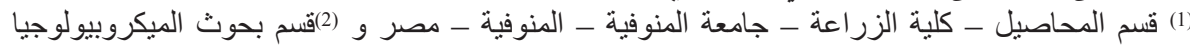
الزر اعية ـ معهد بحوث الأر اضي و المياه و البيئة ـ مركز البحوثة الزئة الزر اعية ـ الجيزة ـ القاهره ـ مصر.

أجريت تجربتان معملية وحقلية بمعل قسم المحاصيل، بالمزر عة التجريبية لكلية الزر اعة بثبين الكوم جامعة

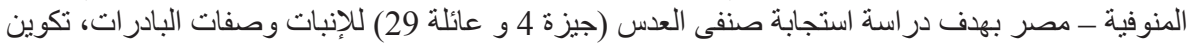

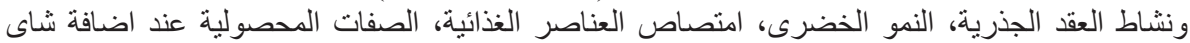

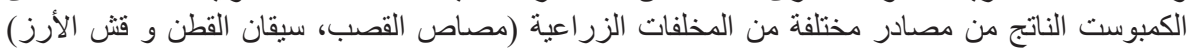

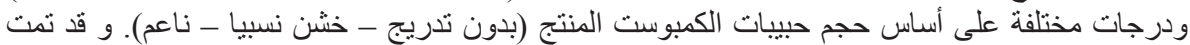

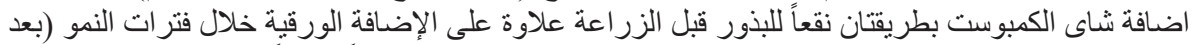

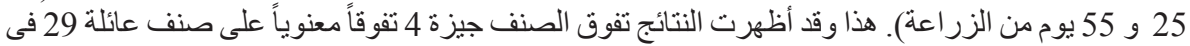

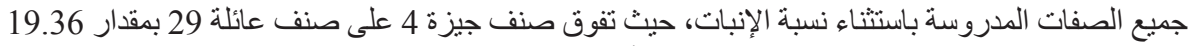
و 11.30\% لصفة محصول البذور خلال الموسم الأول و الثنانى على الترنيب.

سجلت معاملات شاى الكمبوست الناتج من كمبوست سيقان القطن أو فش الأرز ذو حجم الحبيبات الناعم

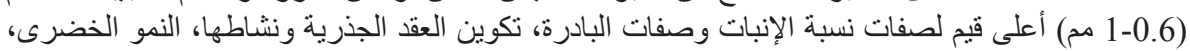

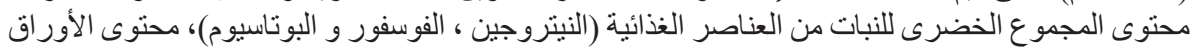

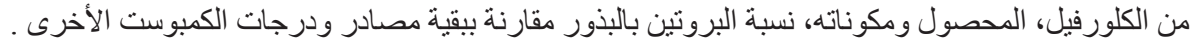

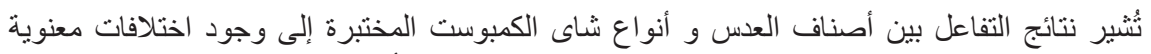

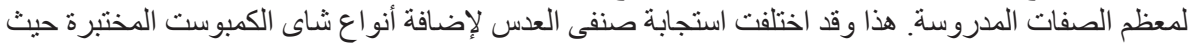

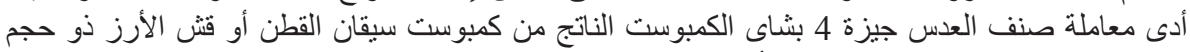

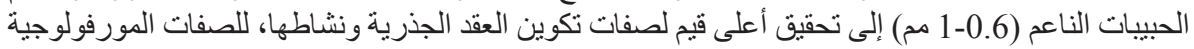
و المحصولية للعدس، مما يشير إلى أهمية استخدام شاى الكمبوست فئ فئ تعظيم إنتاجية العدس . 